\title{
DIE LIBERALISME EN SY INVLOED IN SUID-AFRIKA
}

II.

LIBERALISTIESE TENDENSE IN DIE ONDERWYS.

Die liberale rigting van die negentiende eeu was 'n wye wêreldbegewing wat in alle lande tot openbaring gekom het en sy invloed laat voel het op elke terrein van die lewe. Veel van die koorsagtige bedrywigheid wat die geestelewe van die vorige eeu kenmerk, moet toegeskrywe word aan die besieling van die liberalisme wat tot elke lewenskring deurgedring het met ' $n$ vaste program en 'n eie ideaal. Dit is maar alte waar dat die geseënde Calvinistiese gedagte dat elke duimbreed van die lewe aan die koningsgesag van Christus onderwerp moet word, by wye kringe van die Christelike wêreld eeue lank ingesluimer of totaal verdwyn het. En so is die voorstanders van die liberalisme in die geleentheid gestel om die lewensterreine wat braak gelê het, te beset en oral hul program en boodskap vir 'n nuwe orde te propageer. Hulle het ' $n$ doelbewuste poging aangewend om Christendom en kultuur te versoen, om die teenstrydighede tussen die grondstellinge van die Christelike geloof en die resultate van die moderne wetenskap uit die weg te ruim en om hulle ideaal, baie waarvan aan die Calvinisme ontroof maar met 'n vreemde gedagte-inhoud besiel is, aan die wêreld te verkondig. Alle instellinge van die kultuurlewe-kerk en skool, toneel en drukpers-is dan ook gebruik, soms selfs misbruik, om hierdie doel te bereik.

Uit alle hoeke van die lewe het vrysinnige geeste in die negentiende eeu saamgekom om die liberale broederskap te vorm wat sy nuwe beskouinge as blinkende ideale vir die mensheid met veel ingenomenheid en selftevredenheid voorgehou het. Aan ideale het dit nie ontbreek nie. Vryheid, verligting, volksverligting, vooruitgang, beskawing, hervorming, verandering, verbetering, omwenteling - almal was slagspreuke op die vaandels van die liberale beweging. Hierdie woorde is as strydkrete aangehef op die publieke verhoog, op die kansel en die kateder.

Ook, miskien veral, die opvoeding is gebruik as 'n kanaal waarlangs hierdie nuwe denkbeelde deurgestuur kon word na die lewensakker. Dit is maklik te begryp. Die positiwistiese wêreldbeskouing waarin die liberalisme 'n sterke bondgenoot gevind het, het baie invloed uitgeoefen op die moderne wetenskap en so beheersende betekenis gekry in die opvoeding. 
Die opvattinge van Auguste Comte, J. S. Mill, T. Huxley, E. Renan, Herbert Spencer, manne wat in baie opsigte gebreek het met die tradisionele Christendom, het in die onderwys-wêreld 'n ontvanklike bodem gevind en so kom daar in die negentiende eeu 'n opvoedkundige rigting op wat die grondbeginsels van die Christendom tersyde stel en 'n eie stelsel op 'n nuwe grondslag opbou. Ons sien dit in Amerika waar reeds vroeër die Universiteit van Harvard in liberale koers beweeg het; en in Engeland, waar onderwys nog altyd as kerksaak beskou was, ontstaan die stryd oor staatsinmenging in die skool.

Betekenisvol vir ons land is veral die nuwe opvoedkundige rigtinge in Nederland, waar die ideaal van 'n Christelike skool reeds sedert die dae van die Dordtse Sinode bestaan. Uit die onderwyswetgewing, by name in dié van die jare 1801, 1803, 1806 en 1857, spreek daar 'n nuwe gees wat gaandeweg die hele onderwys-wêreld benewel en die weg baan vir die berugte "Wet op Hooger Onderwys" van 1878 waardeur die teologiese fakulteite in Nederland só omgeskep is dat alleen nog maar die godsdienswetenskap daar tuishoort.

Aan die Kaap was die onderwys op Nederlandse lees geskoei: die gees van die Dordtse Sinode deurstraal aanvanklik die opvoeding soos ook blyk uit die bekende Chavonnes-ordonnansie van 1714, waar nadruk gelê word op die noodsaaklikheid van „bequame en godvresende leermeesters” wat deur die Kerkraad ondersoek moet word en die Dordtse ondertekeningsformulier moes onderskryf. Maar wat in Europa gebeur het, het ook na Suid-Afrika deurgewerk en so kry ons in 1782 'n nuwe reglement waarin die godsdienstige verantwoordelikhede van onderwysers in uiters vae terme omskrywe word. Hierdie wet openbeer die gees van verligting, wat ook langs ander kanale ons land binnegedring het gedurende die agtiende eeu.

Daar is verskeie gevalle bekend van onderwysers en ander wat uiters vrysinnige beskouinge omtrent die Skrif en die Christus van die Skrifte verkondig het, heeltemal op voetspoor van rasionalistiese denkers uit Europa Een interessante geval het ons in die Duitse predikant wat met die Wurttemburgse Regiment na die Kaap gekom het en in 1788, na 'n besoekreis in die binneland, ' $n$ uitvoerige verslag oor die onderwys aan die Politieke Raad voorlê, 'n dokument waaruit die gees van die Franse filosoof Rousseau duidelik spreek. En so is vrysinnige denkbeelde reeds vroeg ingedra in die onderwyslewe van Suid-Afrika.

'n Kragtige stoot in liberale rigting kry die onderwys met die „SchoolOrdre" van De Mist (1803-1806) waarin die beeld van 'n neutrale volkskool betreklik duidelik geteken staan en die onderwys in die Gereformeerde 
geloofsleer vervang word deur 'n godsdiens bokant alle gelofsverdeeldheid. Die ideale van De Mist het weerklank gevind by baie hier te lande, veral in kringe waar die ou Patriotte-gees nog voortgewerk het. Veel moois was daar in sy werk, maar die skeiding van kerk en skool en die sekularisering van die onderwys as 'n middel tot algemene „volksverligting” soos deur hom voorgestaan, berus op beginsels wat in Nederland heftig bestry is en in Engeland eers in 1863-en na langdurige stryd-toegepas kon word. Sy gesindheid blyk ook uit sy opmerkinge oor die noodsaaklikheid van goeie skole. „In de directie er over," so verklaar hy, ,moeten kundige mannen zyn, en wynige of geene geestelyken-deeze laatste smooren alle liberale denkbeelden, kunnen mischien Christenen vormen, maar veelal ellendige leeden voor eene Maatschappy, die veel activiteit behoeft."

Hierdie gees het deurgewerk, veral in die „Maatschappy tot Nut van't Algemeen" wat hier op Nederlandse voorbeeld gestig is en deur die bekende skool, "Tot Nut," wye invloed op onderwys-gebied uitgeoefen het. Weliswaar het die Kerk in die praktyk invloed uitgeoefen wat hom in teorie ontsê is; ook het daar na 1806 onder Engelse bewind verandering gekom en is die samewerking van predikante en landsburgers gesoek ,to contribute to the more extensive circulation of the Scriptures in the Colony and the establishment of a solid system of education "(Sir John Cradock)' maar tog is in hoofsaak die beginsel van De Mist gehandhaaf. In 1839 word die eerste S.G.O. (Superintendent-Generaal van Onderwys) aangestel op aandrang van sir John Herschel, wat die opvoeding as staatsaak beskou het, en reeds twee jaar vroeër het kol. Bell die koloniale sekretaris, duidelik gestipuleer dat hy moet wees ,, a sound, clearheaded man, either not belonging to the ministry or so untinctured with prejudice in favour of this or that form of Christian Protestant faith. as to constitute him an impartial Director General of Public Schools in this Colony."

Deur hierdie beleid is alle dogmatiese onderrig uit die skoolprogram verban. Die bevindinge van die Watermeyer-kommissie (1863) het aan die lig gebring met watter ongelukkige gevolge: In sy sendingskole het die kerk volgehou met leerstellige onderwys aan die hand van die Kategismus; in die publieke skool egter is alles van dié aard geweer-,"nothing beyond reading the Bible and prayers." Hierdie kommissie egter het in sy aanbevelinge nog 'n stap verder gegaan en aanbeveel dat ook Bybelonderrig uitgesluit behoort te word by die gewone dagprogram van die skool en alleen mag geskied ,at an hour set apart by them for that purpose, in addition to the ordinary school hours."

Die Wet no. 13 van 1865 waardeur hierdie beleid vasgelê is, het ons Suid-Afrikaanse skool tot 'n godsdienslose skool verklaar! 
Ook uit die geskiedenis van onderwys-inrigting blyk baie duidelik die liberalistiese tendens. Die vereniging „Tot Nut van't Algemeen” is gestig deur "yverige beoefenaars van den natuurlyken Godsdienst" en prof. N. J. Hofmeyr plaas hierdie beweging in 1854 onder die vaandel van die liberalisme: „,wat hen tezamen vereenigde was niet de belijdenis, maar de verloochening der uitsluitend Christelijke waarheden." Wat in die Tot Nutskool van die godsdiens oorgebly het, was 'n bloedarme godsdiens bokant alle geloofsverdeeldheid.

Ook die Z.A. Athenaeum het in hierdie rigting voortbeweeg, ondanks skerpe kritiek op die skool. Manne soos J. G. Swaving, A. N. E. Changuion, J. W. G. van Oordt, Leipold Marquard, almal sterk voorstanders van die liberalisme op kerklike terrein, het 'n beslis liberalistiese stempel op die onderwys afgedruk, veral in hul ywer vir die sgn. ,zedelijke godsdienst", „de Vrijdom van het geweten" e.d.m.-woorde waarin die gees van De Mist as't ware beliggaam was.

Reeds so vroeg as 1829 waarsku „Een vriend van ware verlichting” dan ook teen die gees wat aan die Athenaeum heers en uit ander oord word beweer dat dit weinig beter is ,dan eene School van Ongeloof." In 1830 het rev. E. Judge ook teenoor die Athenaeum 'n eie inrigting opgerig, „from whose walls”, so het hy verklaar, „religious Instruction shall not be excluded, but shall from an essential part of the course of Education." In $1840 \mathrm{kom}$ 'n blad soos The Grahams Town Journal met 'n ernstige waarskuwing teen die opkommende rigting om godsdiensonderrig van die opvoeding te skei, ,in accordance with the liberalism of the present day,"

Dit is eienaardig dat Kaapse predikante, opgevoed op die vasteland van Europa, die gevaar van hierdie rigting minder sterk aangevoel het as Engelse leraars wat in hul moederland aan iets beters gewoond was. Manne soos dr. S. P. Heyns en ds. A. Faure het voortgegaan om mee te werk aan hierdie inrigtinge, ondanks sware kritiek van alle kante. Van ds. G. W. A. van der Lingen moes hulle verneem dat hierdie soort skole "uit de Revolutie voortgesproten waren" en ook in die openbere pers gaan gerugte rond van onderwysers „die voorgeven Christenen te zyn . . .die nogtans de Godheid van Christus ontkennen! En op 24 Oktober 1864 vertel DE ZUID-AFRIKAAN van „een voormalig Professor aan het Zuid Afrikaansche College .... die wiskunde en ongeloof leerde!"

Teen hierdie tyd het dit egter al duidelik geblyk waarom die stryd gaan: die agitasie vir Christelike onderwys is afgewys deur die liberale pers as 'n poging om die liberalisme te bestry, voorstanders van Christelike onderwys is as teenstanders van ware vooruitgang bestempel, terwyl die kritiek 
op destyds heersende toestande as ongelukkige voorbeelde van bekrompenheid bespot is. Maar so het dit ook duidelik geword dat die stryd om die onderwys. veral na 1865, almeer stryd vir of teen die liberalisme geword het. Vandaar dat ds. J. H. Neethling van Stellenbosch in 1873 waarsku teen die ,wereldsche scholen... waarin de geest der wereld" voortwerk. Hieruit is gebore die aksie vir die Vrye Christelike Skool, vaaraan di. S. J. du Toit en W. P. de Villiers in die Kaapse Sinode en Parlement hul beste kragte gewy het. Weliswaar het dit tot gevolg gehad dat onder leiding van Jan Hofmeyr (Onze Jan) in 1886 'n wet deur die Kaapse Parlement aangemeem is wat aan skoolkomitees die reg gee om voorsiening te maak vir godsdiensonderrig ,gedurende gewone schooluren." Hiermee egter is die wet van 1865 verander, maar die stelsel het onveranderd gebly en die gewetensklousule is gehandhaaf, ,'n skyn verandering" na die oordeel van ds. S. J. du Toit

Tog het dit die oë van baie verblind totdat dit... te laat was! Die Freemantle-Kommissie (1912) werp 'n bedenklike lig op die opvoedkundige beginsels en beleid van ons land in die negentiende eeu. Daaruit leer ons dat (a) die Bybel uit haas alle skole verdwyn het, (b) onkunde omtrent die Heilige Skrif ontsettende vorme aangeneem het en (c) agtelosigheid ten opsigte van openbare sedelikheid vererg het. Die kommissie boekstaaf dit as sy bevinding ,that the system of law and regulations as now administered by the various educational authorities results in practice in general inattention to the religious and moral elements of education and in widespread ignorance of the Scriptures, amounting at times to something like the paganisation of the people, and likely, if not checked, to advance and increase in intensity."

In die omwenteling op die gebied van onderwys en opvoeding in SuidAfrika gedurende die negentiende eeu kan ons dus die liberale koers duidelik onderskei.

(a) die skeiding tussen kerk en skool onder De Mist;

(b) die verbanning van alle leerstellige onderwys uit die skool in 1839 ;

(c) die skeiding tussen die skool en die Heilige Skrif in 1865 .

Ook in ander lande het ons in daardie eeu dieselfde verskynsels: In Engeland word die kerk uit die onderwys verdring deur die Staat; in Nederland neem die sekularisering van die onderwys steeds sterker vorme aan. Ook in Amerika kry ons ,the demands of liberalism". Daar het ons in 
1872 'n liberale manifes waarin as eise vervat is (a) ,that all public appreciation of educational institutions of a sectarian character shall cease," en (b) ,that the use of the Bible, in public Schools, whether ostensibly as a text-book or avowedly as a book of religious worship, shall be prohibited."

Hierdie eise is nie in Suid-Afrika by wyse van 'n manifes gestel in 1872 nie. Dit was ook nie nodig nie, want hierdie beginsels was toe reeds lankal ingevoer in ons opvoeding, beide in die onderwys-inrigting en in die wetgewing: alle steun is van sgn. sektariese (kerklike) skole weerhou en ook die Bybel is uit die publieke skool se dagprogram verwyder. Dit gee aan ons die reg om te praat van liberalistiese tendense in ons onderwys en opvoeding in 'n baie pertinente sin.

Insiggewend is ook die feit dat die liberale metode aan die liberale beginsel voorafgegaan het; wat in die onderwys-inrigting as beleid ingevoer is, word eers later deur wetgewing gesanksioneer!

By dit alles was daar in hierdie tyd hooggespanne verwagtinge op die opvoeding gerig: „De beschaving, de opvoeding zal de zonde minder maken, en de deugd doen toenemen." Maar die grootskaalse eksperiment om opvoeding sonder godsdiens as bate vir Suid-Afrika aan te wend, het veelal misluk met noodlottige gevolge vir die jeug. Die getuienis van 'n edel Christen en hoogstaande opvoedkundige, prof. J. I. Marais van Stellenbosch, voor die kommissie van 1912 is hier afdoende: „There are undoubted signs of the invasion of this country by the spirit of frigid intellectualism such as is generally observed where education is divorced from religion and is as a rule accompanied by a great laxity of morals which sweeps away the national spirit and the individual character."

Hier word die liberalistiese tendens in ons opvoeding gedurende die negentiende eeu en die noodlottige gevolge daarvan o.i. baie waar geteken!

T. N. Hanekom. Kaapstad. 